\title{
GLI Family Protein
}

National Cancer Institute

\section{Source}

National Cancer Institute. GLI Family Protein. NCI Thesaurus. Code C17701.

A group of DNA-binding proteins that contain zinc finger repeats and involves pattern formation process. 